\title{
IDENTIFICATION OF BENr GENE FROM CANDIDA ALBICANS IN SPUTUM SAMPLES
}

\author{
Prasobh Krishnan Karukappillil'1, Riyaz Sherif², Lakshmi Sarayu³ ${ }^{3}$ Simi $^{4}$
}

${ }_{1}^{1}$ Associate Professor, Department of Microbiology, AIMSR, Kollam, Kerala, India.

${ }^{2}$ Assistant Professor, Department of Microbiology, AIMSR, Kollam, Kerala, India.

3 Professor and HOD, Department of Microbiology, AIMSR, Kollam, Kerala, India.

4 Tutor, Department of Microbiology, AIMSR, Kollam, Kerala, India.

\begin{abstract}
BACKGROUND

Candidiasis is caused by infection with species of the genus Candida, predominantly with Candida albicans. The growing problem of mucosal and systemic candidiasis reflects the enormous increase in the number of patients at risk and the increased opportunity that exists for Candida species to invade tissues that are normally resistant to invasion with the help of the Candida virulence markers such as adhesin, Germ tube, Pseudohyphae, slime production, exoenzymes etc. The respiratory tract is frequently colonized with Candida species, especially in hospitalised patients. The drug resistance shown by Candida is increasing day-by-day. The most common gene responsible for multi-drug resistance was noted as BENr.
\end{abstract}

\section{MATERIALS AND METHODS}

Candida albicans was isolated from the sputum by conventional methods. Antifungal susceptibility testing was done, and multidrug-resistant strains were subjected to genotyping to identify BENr gene by multiplex PCR.

\section{RESULTS}

From a total of 561 Candida albicans strains, 68 of them were multi-drug resistant and four strains have BENr gene.

\section{CONCLUSION}

BENr gene, which is responsible for multidrug resistance in Candida was present in our region.

\section{KEY WORDS}

Multi-Drug Resistance, Candida albicans, BENr Gene.

HOW TO CITE THIS ARTICLE: Karukappillil PK, Sherif R, Sarayu L, et al. Identification of BENR gene from candida albicans in sputum samples. J. Evolution Med. Dent. Sci. 2018;7(37):4088-4090, DOI: 10.14260/jemds/2018/914

\section{BACKGROUND}

The incidence of fungal infections, especially candidiasis has increased significantly over the past two decades, particularly among immunocompromised people. ${ }^{1}$ Compared to other medically important fungi, Candida albicans remains the most persistent and pervasive yeast pathogen in humans, capable of invading virtually every tissue of the body.2,3

Candidiasis is caused by infection with species of the genus Candida, predominantly with Candida albicans. The growing problem of mucosal and systemic candidiasis reflects the enormous increase in the number of patients at risk and the increased opportunity that exists for Candida species to invade tissues normally resistant to invasion with the help of the Candida virulence markers such as adhesin, Germ tube, Pseudohyphae, slime production, exoenzymes etc.

High-risk areas for Candida infection include neonatal, paediatric and adult ICUs, both medical and surgical ${ }^{4}$ and Candida infections can involve any anatomical structure. The management of serious and life- threatening

'Financial or Other Competing Interest': None.

Submission 18-07-2018, Peer Review 25-08-2018,

Acceptance 01-09-2018, Published 03-09-2018.

Corresponding Author:

Dr. Prasobh Krishnan Karukappillil,

Associate Professor,

Department of Microbiology,

Azeezia Institute of Medical Sciences and Research,

Kollam, Kerala, India.

E-mail: prasobh13@gmail.com

DOI: $10.14260 /$ jemds $/ 2018 / 914$ invasive candidiasis remains severely hampered by delays in diagnosis and the lack of reliable diagnostic methods that allow detection of both fungemia and tissue invasion by Candida species.

The respiratory tract is frequently colonized with Candida species, especially in hospitalised patients. Approximately, $20-25 \%$ of ambulatory patients are colonised with Candida species. Respiratory tract Candidiasis such as laryngeal candidiasis, Candida tracheobronchitis and Candida pneumonia seems to be the most prevalent types of respiratory tract Candidiasis and needs attention of the clinician as well as research scientists to have proper solution. ${ }^{5}$ The drug resistance shown by Candida is increasing day-by-day. So, it was necessary to conduct a study about it and to find out the CaMDR1 gene from Candida albicans.

\section{MATERIALS AND METHODS}

The subjects included were the patients with signs and symptoms of chronic respiratory tract infection attending the TB clinics at Rajah Muthiah Medical College, Mahatma Gandhi Medical College, and various private nursing homes in and around Chidambaram. A total of 3100 sputum samples were collected for the study.

Early morning sputum samples of three days consecutive were collected after a deep cough in sterile containers. Collected samples were screened for yeast cells with or without pseudohyphae by Gram's staining as well as $10 \%$ $\mathrm{KOH}$ wet mount examination. Sputum samples were inoculated on SDA plates with chloramphenicol and observed for typical creamy, mucoid, smooth, pasty colonies with 
yeasty odour. Species identification was performed by Sugar fermentation, Sugar Assimilation, Germ tube production and colony morphology on Hi-Chrome agar. For antifungal susceptibility testing, initially the isolated Candida albicans were screened by disc diffusion method and resistant strains further identified by dilution method. The multidrugresistant strains were then subjected to genotyping by multiplex PCR.

\section{Multiplex PCR for Identification of Resistance Gene Isolation of Genomic DNA/ Procedure}

$1.5 \mathrm{~mL}$ of Candida transferred to a microcentrifuge tube and centrifuged at 20,000 rpm for 1 - 5 minutes. Then added 200 $\mu \mathrm{L}$ of Harju-buffer and immersed in a dry ice ethanol bath for 2 mins. Kept at a $95^{\circ} \mathrm{C}$ water bath for 1 minute. After adding $200 \mu \mathrm{L}$ of chloroform, centrifuged at $20,000 \mathrm{rpm}$ for $3 \mathrm{mins}$ the supernatant transferred to $400 \mu \mathrm{L}$ ice-cold $100 \%$ ethanol and mixed thoroughly. After 5 mins keeping at room temperature, centrifuged and supernatant removed, pellets were washed with $0.5 \mathrm{~mL} \mathrm{70 \%} \mathrm{ethanol,} \mathrm{again} \mathrm{centrifuged} \mathrm{and}$ removed supernatant. Air dried it and re-suspend in 25-50 $\mu \mathrm{L}$ distilled water.

\section{Reagents}

- Harju-Buffer

- $2 \%$ Triton X-100

- $1 \%$ SDS

- $100 \mathrm{mM} \mathrm{NaCl}$

- 10 mM Tris-HCl, pH 8.0

- 1 mM EDTA

\section{Confirmation of DNA by Agarose Gel Electrophoresis}

Agarose gel electrophoresis was carried out in a horizontal submarine electrophoresis unit. Thirty $\mathrm{mL}$ of $1 \%$ Agarose gel was prepared with $1 \mathrm{X}$ TBE buffer (do not mix) and the content heated to get a clear solution for casting Agarose gel. After cooling the solution, $7 \mu \mathrm{L}$ of staining dye solution was added into the casting system.

The gel was allowed to solidify and then carefully disassembled from the casting system without disturbing the wells and placed in $1 \mathrm{X}$ TBE buffer filled electrophoresis tank, ensuring that the buffer level stayed above the gel). $5 \mu \mathrm{L}$ of genomic sample DNA was mixed with $2 \mu \mathrm{L}$ of gel loading dye and then loaded to gel. Simultaneously, $3 \mu \mathrm{L}$ of DNA marker provided was loaded in the nearby well.

The power card terminals were connected at respective positions, and the gel was allowed to run at $50 \mathrm{~V}$ till the gel loading dye migrated more than half the length of the gel. Then switched off the unit and visualised the isolated DNA was under a UV Transilluminator.

\section{X TBE Buffer}

$\begin{array}{lll}\text { Tris base } & : & 10.8 \mathrm{~g} \\ \text { Boric acid } & : & 5.5 \mathrm{~g} \\ \text { EDTA } & : & 0.92 \mathrm{~g} \\ \text { Distilled water } & : & 1000 \mathrm{~mL} \\ \text { PH } & : & 8.3 \\ & & \\ \text { 1X TE Buffer } & & \\ \text { Tris base } & : & 10.8 \mathrm{~g} \\ \text { EDTA } & : & 0.92 \mathrm{~g} \\ \text { Distilled water } & : & 1000 \mathrm{~mL} \\ \text { PH } & : & 8.0\end{array}$

\section{Sample Loading Dye}

Sucrose $40 \%$ and bromophenol blue $(0.25 \%)$ were mixed with sterile double distilled water.

\section{Ethidium Bromide}

Ethidium bromide (10 mg) was mixed with $10 \mathrm{~mL}$ of sterile distilled water. (It is carcinogenic and should be treated or handled accordingly).

\section{Polymerase Chain Reaction}

All the available partial and full-length gene sequences of resistance gene were determined according to Sanglard protocol with some modification. The primers were obtained from Sigma, India and used in the PCR comprised Primer CDR1 - 5'GTT GTT TTG GGG AGA CCC GGT GCT ' 3 and CDR2 5'CTT ACC AGC ACC AGA TGC TCC CAT'3, BENR 1-5' AAA AGC TTA TGC ATT ACA GAT TTT TAA GAG'3 and BENR 2- 5'AAA AGC TTC TAA TTA GCA TAC TTA GAT CTT'3.

The PCR mix was prepared in thin walled PCR tube in a sterile laminar flow hood, and the reagents were added as follows: -

Each PCR reaction mixture $(20 \mu \mathrm{L})$ contained $2 \mu \mathrm{L}$ of template DNA (plasmid DNA), $2 \mu \mathrm{L}$ of $10 \mathrm{X}$ PCR buffer, $0.5 \mu \mathrm{L}$ of $(0.5 \mu \mathrm{M})$ each of the primers, $1 \mu \mathrm{L}$ of $0.2 \mathrm{mM}$ of each deoxynucleotide triphosphates (dNTPs) and $1 \mu \mathrm{L}$ of Taq DNA polymerase (Con. $5 \mathrm{U} / \mu \mathrm{L}$ ) and $8.0 \mu \mathrm{L}$ of molecular grade water. A brief spin was given for the materials to settle down, and then tubes were kept in thermocycler (Genei). After initial denaturation at $94^{\circ} \mathrm{C}$ for 4 mins, the samples were subjected to 30 cycles of denaturation at $94^{\circ} \mathrm{C}$ for 30 secs, annealing at $54^{\circ} \mathrm{C}$ for $1 \mathrm{~min}$ and extension at $72^{\circ} \mathrm{C}$ for 2 mins. A final extension was performed at $72^{\circ} \mathrm{C}$ for 10 mins. Following PCR, aliquots $(20 \mu \mathrm{L})$ of the reaction mixtures were analysed by electrophoresis on a $1.5 \%$ Agarose gel containing ethidium bromide $(0.2 \mathrm{mg} / \mathrm{mL})$, in the presence of an appropriate DNA molecular weight marker. The amplification band was observed under UV Transilluminator and detection of resistance gene was done with the use of marker.

\section{RESULTS}

\begin{tabular}{|c|c|c|c|}
\hline $\begin{array}{l}\text { Sl. } \\
\text { No }\end{array}$ & $\begin{array}{l}\text { Name of the } \\
\text { Institution }\end{array}$ & Sputum Samples & $\begin{array}{c}\text { No. of } \\
\text { Isolates }\end{array}$ \\
\hline 1 & RMMC and $\mathrm{H}$ & 1300 & 281 \\
\hline 2 & MGMC and RI & 1150 & 211 \\
\hline 3 & PNC & 650 & 146 \\
\hline & Total & 3100 & 638 \\
\hline \multicolumn{4}{|c|}{$\begin{array}{c}\text { Table 1. Distribution of the Sputum Specimens and } \\
\text { Candida Culture Result }\end{array}$} \\
\hline
\end{tabular}

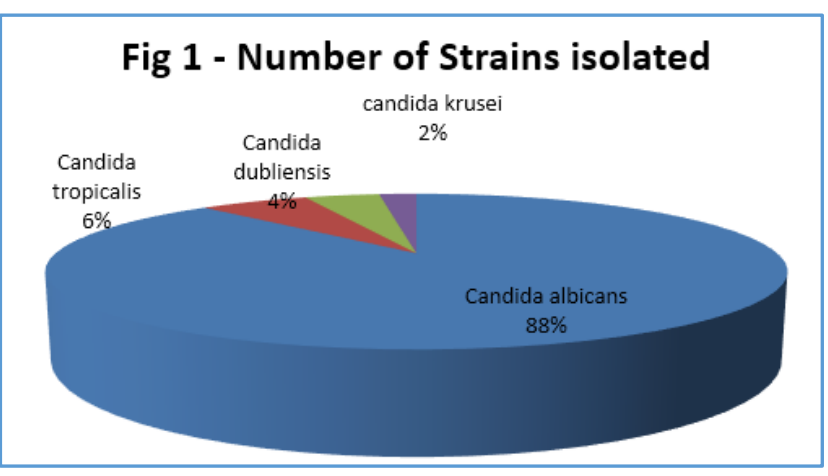




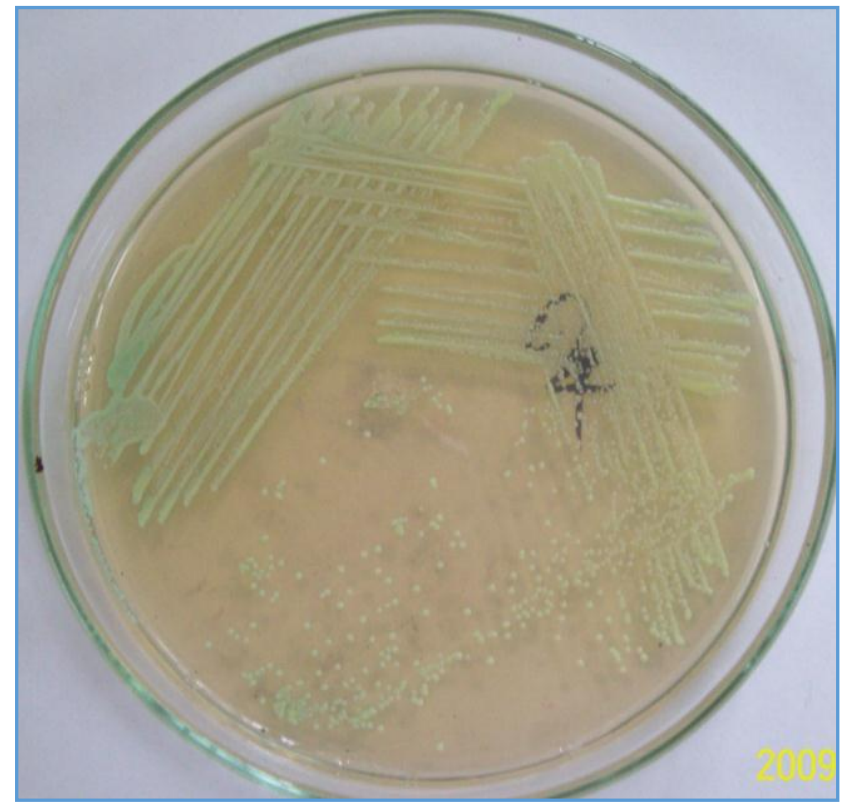

Figure 2. Candida albicans on Chrom Agar

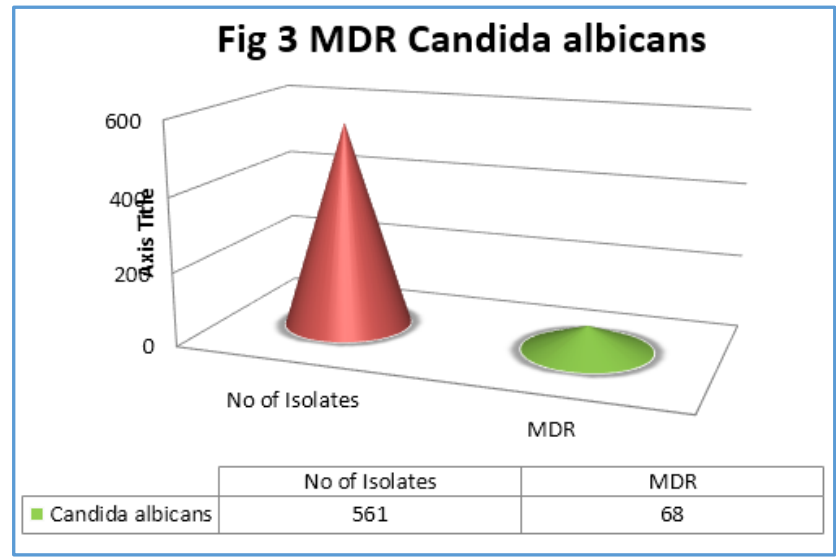

$\begin{array}{llllllllll}1 & 2 & 3 & 4 & 5 & 6 & 7 & 8 & 9 & M\end{array}$

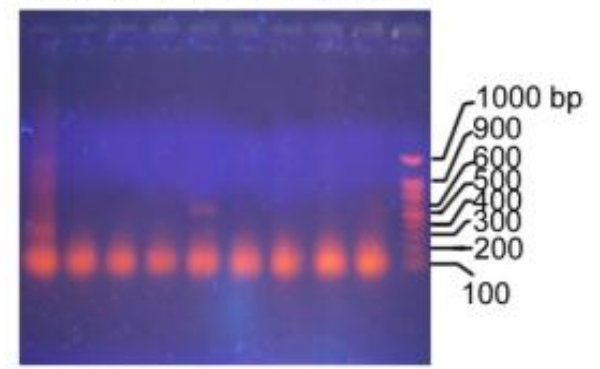

1- SO4, 2-583, 3-421, 4-012,5-387,6-602,7-021, 8-009 9-006, M- 100 bp DNA ladder

Figure 4. $P C R$

\section{DISCUSSION}

From a total of 3100 sputum samples, 638 Candida strains were isolated (Table 1). The predominant species was Candida albicans (561) followed by Candida tropicalis (38), Candida dubliniensis (26) and Candida krusei (13) (Fig. 1). All the Candida albicans were subjected for antifungal susceptibility testing and 68 of them were found to be resistant to all antifungal agents (Fig. 3).

These 68 multidrug-resistant Candida albicans strains subjected to the genotyping by PCR, for the detection of BENr (CaMDR1) gene. Among 68 MDR Candida albicans strains, four (4) strains were found to possess BENr gene.

Candida albicans is one of the first eukaryotic pathogens selected for genome sequencing. It is the most commonly isolated yeast in laboratories, accounting for nearly $80 \%$ 6isolates. Recent advances in molecular biology-based technology enabled detailed analysis of the genetic diversity of $C$. albicans and some groups of $C$. albicans strains have been genetically characterised and reported.7,8

Though numerous recent publications indicating the genotyping of Candida with their different characters have been made, only occasional literatures are available about genotyping of drug resistant Candida. Ben-Yaacov et al in 1994 suggested BENr gene was responsible for multidrug resistance in Candida albicans. ${ }^{9}$ To the best of our knowledge, there is no Indian publication available about the multidrugresistant Candida within the human respiratory tract.

\section{CONCLUSION}

We were able to record 6\% MDR Candida possessed BENr (CaMDR1) gene. Further, our study on Genotyping of MDR Candida is limited by the few number of strains tested, and the results might vary when more number of MDR Candida strains are tested. To bring out new results and information, further extensive study is essential.

\section{REFERENCES}

[1] Richardson M, Lass-Florl C. Changing epidemiology of systemic fungal infections. Clin Microbiol Infect 2008;14(Suppl 4):5-24.

[2] Bodey GP, Fainstein V. Candidiasis. New York: Raven Press 1985

[3] Kirkpatrick CH. Chronic mucocutaneous candidiasis. Eur J Clin Microbiol Infect Dis 1989;8(5):448-56.

[4] Kurtzman CP, Fell JW. The Yeasts a taxonomic study. $4^{\text {th }}$ edn. New York, NY: Elsevier Science 1998: p. 14852.

[5] Odds FC. Candida and Candidosis. Baltimore: University Park Press 1978.

[6] Rex JH, Walsh TJ, Sobel JD, et al. Practice guidelines for the treatment of candidiasis. Infectious Diseases Society of America. Clin Infect Dis 2000;30(4):662-78.

[7] Pappas PG, Rex JH, Lee J, et al. A prospective observational study of candidemia: epidemiology, therapy, and influences on mortality in hospitalized adult and pediatric patients. Clin Infect Dis 2003;37(5):634-43.

[8] Lopez-Ribot JL, Casanova M, Martinez JP, et al. Characterization of cell wall proteins of yeast and hydrophobic mycelial cells of Candida albicans. Infect Immun 1991;59(7):2324-32.

[9] Ben-Yaacov R, Knoller S, Caldwell GA, et al. Candida albicans gene encoding resistance to benomyl and methotrexate is a multidrug resistance gene. Antimicrob Agents Chemother 1994;38(4):648-52. 